\title{
Parapedobacter luteus sp. nov. and Parapedobacter composti sp. nov., isolated from cotton waste compost
}

Correspondence

Soon-Wo Kwon

swkwon@rda.go.kr

\author{
Soo-Jin Kim, ${ }^{1}$ Hang-Yeon Weon, ${ }^{1}$ Yi-Seul Kim, ${ }^{1}$ Seung-Hee Yoo, ${ }^{1}$ \\ Byung-Yong Kim, ${ }^{1}$ Rangasamy Anandham ${ }^{2}$ and Soon-Wo Kwon ${ }^{1}$
}

\footnotetext{
${ }^{1}$ Korean Agricultural Culture Collection (KACC), National Agrobiodiversity Center, Suwon 441-707, Republic of Korea
}
${ }^{2}$ Agricultural Microbiology, Department of Agricultural Microbiology, Agricultural College and Research Institute, Madurai, India

Two aerobic, Gram-reaction-negative, non-spore-forming bacterial strains, $4 \mathrm{M} 29^{\top}$ and $4 \mathrm{M} 40^{\top}$, were isolated from cotton composts. The two strains grew in the presence of $0-5 \%(\mathrm{w} / \mathrm{v}) \mathrm{NaCl}$ (optimum growth in the absence of $\mathrm{NaCl}$ ), at $\mathrm{pH} 6.0-8.0$ (optimum, $\mathrm{pH} 7.0$ ) and at $15-45^{\circ} \mathrm{C}$ (optimum, $30{ }^{\circ} \mathrm{C}$ ). The strains shared $97.1 \% 16 \mathrm{~S}$ rRNA gene sequence similarity. Strains $4 \mathrm{M} 29^{\top}$ and $4 \mathrm{M} 40^{\top}$ showed the next highest levels of $16 \mathrm{~S}$ rRNA gene sequence similarity to Parapedobacter koreensis Jip $14^{\top}$ (95.6 and 94.4\%, respectively) and Parapedobacter soli DCY $14^{\top}$ (95.2 and 93.8\%). The level of DNA-DNA relatedness between strains $4 \mathrm{M} 29^{\top}$ and $4 \mathrm{M} 40^{\top}$ was $38 \%$. The two strains contained iso- $\mathrm{C}_{15: 0}$, summed feature 3 (comprising iso- $\mathrm{C}_{15: 0}$ $2-\mathrm{OH}$ and/or $\mathrm{C}_{16: 1} \omega 7 \mathrm{c}$ ) and iso- $\mathrm{C}_{17: 0} 3-\mathrm{OH}$ as major fatty acids, MK-7 as the major respiratory quinone, homospermidine as the only polyamine and phosphatidylethanolamine as the major polar lipid. The DNA G $+C$ contents of strains $4 \mathrm{M}_{2} 9^{\top}$ and $4 \mathrm{M}^{\top} \mathrm{O}^{\top}$ were 47.6 and $48.6 \mathrm{~mol} \%$, respectively. On the basis of phylogenetic and phenotypic data, strains $4 \mathrm{M} 29^{\top}$ and $4 \mathrm{M} 40^{\top}$ are considered to represent two novel species of the genus Parapedobacter, for which the names Parapedobacter luteus sp. nov. (type strain $4 \mathrm{M} 29^{\top}=\mathrm{KACC} 10955^{\top}=\mathrm{JCM} 15977^{\top}$ ) and

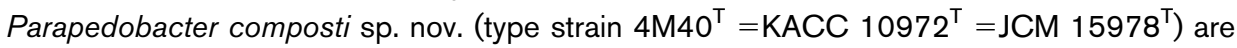
proposed.
The genus Parapedobacter was erected with the description of Parapedobacter koreensis to accommodate a single strain isolated from dried rice straw (Kim et al., 2007). A second species of the genus isolated from soil, Parapedobacter soli, was subsequently described (Kim et al., 2008). The genus belongs to the family Sphingobacteriaceae together with the genera Sphingobacterium (Yabuuchi et al., 1983), Pedobacter (Steyn et al., 1998), Mucilaginibacter (Pankratov et al., 2007), Olivibacter (Ntougias et al., 2007), Pseudosphingobacterium (Vaz-Moreira et al., 2007), Nubsella (Asker et al., 2008) and Solitalea (Weon et al., 2009). Members of the genus Parapedobacter are Gram-reaction-negative, rod-shaped, non-motile bacteria with iso- $\mathrm{C}_{15: 0}$, iso- $\mathrm{C}_{17: 0} 3-\mathrm{OH}$ and summed feature 3 (comprising iso- $\mathrm{C}_{15: 0} 2-\mathrm{OH}$ and/or $\left.\mathrm{C}_{16: 1} \omega 7 c\right)$ as major fatty acids, menaquinone 7 as the

The GenBank/EMBL/DDBJ accession numbers for the $16 \mathrm{~S}$ rRNA gene sequences of strains $4 \mathrm{M} 29^{\top}$ and $4 \mathrm{M} 40^{\top}$ are FJ754320 and FJ754321, respectively.

Thin-layer chromatograms showing the polar lipid profiles of strains $4 \mathrm{M}^{\mathrm{T}}{ }^{\mathrm{T}}, 4 \mathrm{M} 40^{\top}$ and Parapedobacter koreensis Jip $14^{\top}$ are available as supplementary material with the online version of this paper. predominant respiratory quinone and sphingolipid as a characteristic polar lipid.

During the course of a study on the bacterial diversity of cotton waste composts used for the cultivation of the oyster mushroom (Pleurotus ostreatus), we previously isolated several novel bacterial strains by means of the plating technique on trypticase soy agar (TSA, pH 7.0; Difco) at $30{ }^{\circ} \mathrm{C}$. In the present study, we report the taxonomic characterization of two of these bacterial strains, designated $4 \mathrm{M} 29^{\mathrm{T}}$ and $4 \mathrm{M} 40^{\mathrm{T}}$.

The 16S rRNA genes of strains $4 \mathrm{M} 29^{\mathrm{T}}$ and $4 \mathrm{M} 40^{\mathrm{T}}$ were amplified by PCR with primers fD1 and rP2 (Weisburg et al., 1991), and the entire PCR fragment was then directly sequenced (Hiraishi, 1992). 16S rRNA gene sequences were aligned by using the MEGALIGN program (DNASTAR). A phylogenetic tree was constructed by using the software package MEGA version 3.1 (Kumar et al., 2004). Distances (options according to Kimura's two-parameter model) and clustering (via the neighbour-joining and maximumparsimony methods) were determined by using bootstrap values based on 1000 replicates. The level of 16S rRNA gene 
sequence similarity between strains $4 \mathrm{M} 29^{\mathrm{T}}$ and $4 \mathrm{M} 40^{\mathrm{T}}$ was $97.1 \%$. Strains $4 \mathrm{M} 29^{\mathrm{T}}$ and $4 \mathrm{M} 40^{\mathrm{T}}$ showed the next highest 16S rRNA gene sequence similarities to Parapedobacter koreensis $\mathrm{Jip}_{14}^{\mathrm{T}}$ (95.6 and $95.2 \%$, respectively) and Parapedobacter soli DCY14 ${ }^{\mathrm{T}}$ (94.4 and $93.8 \%$ ). The two strains showed sequence similarities of $<92 \%$ with the type strains of other related taxa. In the neighbour-joining phylogenetic tree (Fig. 1), the novel strains clustered with Parapedobacter koreensis $\mathrm{Jip} 14^{\mathrm{T}}$ and Parapedobacter soli DCY $14^{\mathrm{T}}$ with $100 \%$ bootstrap support. This topology was also recovered in the maximum-parsimony tree.

DNA-DNA hybridization experiments between the two new isolates were carried out according to the method of Seldin \& Dubnau (1985). Probe labelling was conducted by using the non-radioactive DIG High Prime DNA labelling and detection starter kit II (Roche Molecular Biochemicals). Reassociation was conducted at $65^{\circ} \mathrm{C}$. The hybridized DNA was visualized by using the DIG luminescent detection kit (Roche) and DNA-DNA relatedness was quantified by using a densitometer (Bio-Rad). The level of DNA-DNA relatedness between strains $4 \mathrm{M} 29^{\mathrm{T}}$ and $4 \mathrm{M} 40^{\mathrm{T}}$ was $38 \%$.

For quantitative analysis of cellular fatty acids, strains $4 \mathrm{M} 29^{\mathrm{T}}$ and $4 \mathrm{M} 40^{\mathrm{T}}$ were grown under the same conditions that had been used for Parapedobacter koreensis $\mathrm{Jip} 14^{\mathrm{T}}$ and Parapedobacter soli DCY $14^{\mathrm{T}}$, i.e. on TSA plates at $30{ }^{\circ} \mathrm{C}$ for 2 days. Cells were harvested and cellular fatty acids were saponified, methylated and extracted as described for use of the Sherlock Microbial Identification System (MIDI, 1999). Fatty acids were analysed by GC (Hewlett Packard 6890) and were identified by using the Microbial Identification software package (Sasser, 1990). Isoprenoid quinones were analysed by HPLC as described by Groth et al. (1996). Polyamines were analysed by HPLC (Shimadzu LC-10A), with the chromatograph equipped with a fluorescence detector (Shimadzu RF-10AXL) and reversed-phase column [Akzo Nobel; Kromasil ODS $(250 \times 4.6 \mathrm{~mm})$ ] as described previously (Busse \& Auling, 1988; Busse et al., 1997). Polar lipids of strains $4 \mathrm{M} 29^{\mathrm{T}}$ and $4 \mathrm{M} 40^{\mathrm{T}}$ and Parapedobacter koreensis Jip $14^{\mathrm{T}}$ were analysed according to Minnikin et al. (1984). DNA G+C contents were determined by HPLC of deoxyribonucleosides as described by Mesbah et al. (1989), by using a reversed-phase column (Supelcosil LC-18 S; Supelco).

The predominant cellular fatty acids of strains $4 \mathrm{M} 29^{\mathrm{T}}$ and $4 \mathrm{M} 40^{\mathrm{T}}$ were iso- $\mathrm{C}_{15: 0}$, summed feature 3 (comprising iso$\mathrm{C}_{15: 0} 2-\mathrm{OH}$ and/or $\mathrm{C}_{16: 1} \omega 7 c$ ) and iso- $\mathrm{C}_{17: 0} 3-\mathrm{OH}$. The complete fatty acid compositions of the novel strains and of the type strains of the two recognized Parapedobacter species are detailed in Table 1 . The fatty acid profiles of strains $4 \mathrm{M} 29^{\mathrm{T}}$ and $4 \mathrm{M} 40^{\mathrm{T}}$ were similar to those of Parapedobacter koreensis Jip $14^{\mathrm{T}}$ and Parapedobacter soli DCY $14^{\mathrm{T}}$ but differed based on the presence or proportions of anteiso- $\mathrm{C}_{13: 0}, 10$-methyl $\mathrm{C}_{16: 0}$, anteiso- $\mathrm{C}_{17: 0}$,

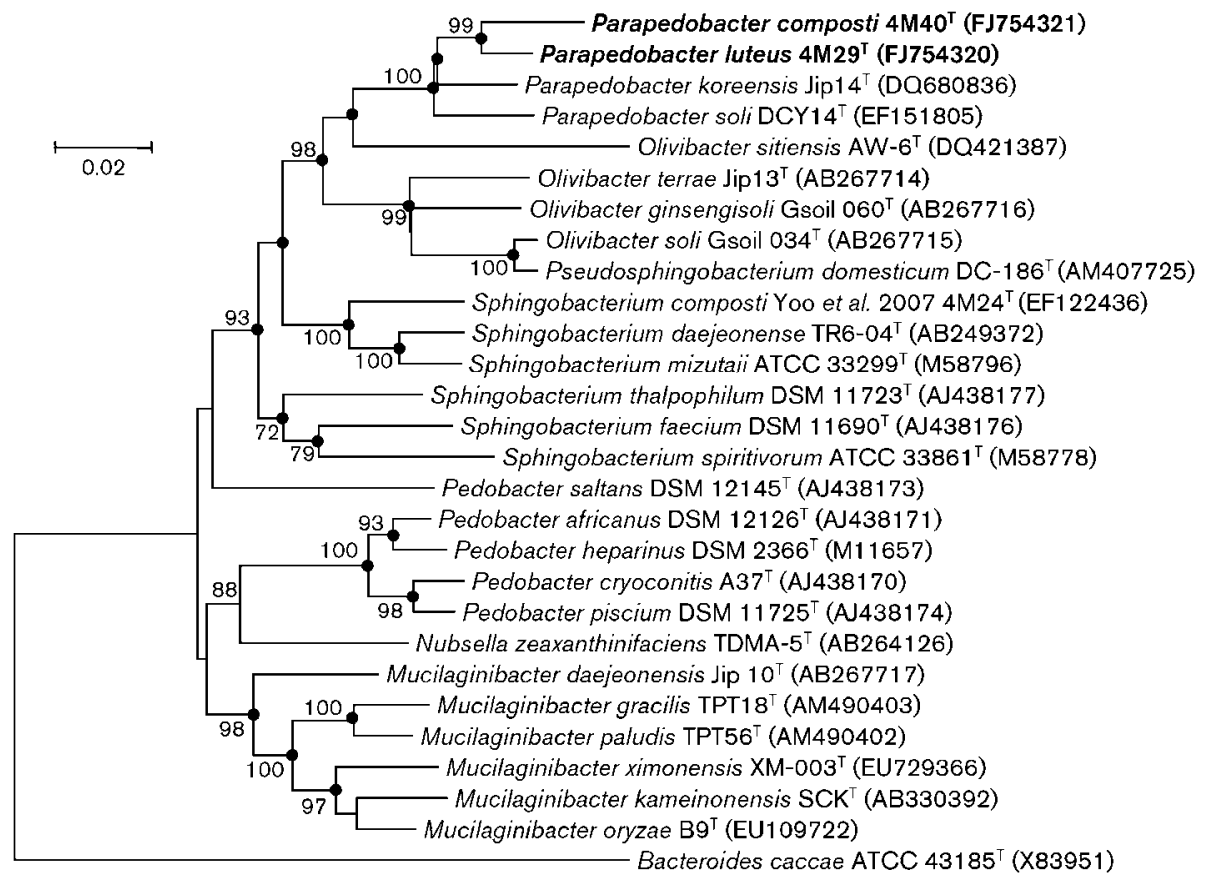

Fig. 1. Neighbour-joining phylogenetic tree based on $16 \mathrm{~S}$ rRNA gene sequences, showing the positions of strains $4 \mathrm{M} 29^{\top}$ and $4 \mathrm{M} 40^{\top}$, the type strains of recognized Parapedobacter species and representative members of the family Sphingobacteriaceae. The sequence of Bacteroides caccae ATCC $43185^{\top}$ was used as an outgroup. Numbers at nodes indicate bootstrap values, expressed as percentages of 1000 replications; only values $>70 \%$ are shown. Dots indicate that the corresponding branches were also recovered in the maximum-parsimony tree. Bar, 0.02 accumulated changes per nucleotide. 
iso- $\mathrm{C}_{17: 1} \omega 9 c$ and ECL 13.566. The two novel strains possessed MK-7 as the major menaquinone, in agreement with all members of the family Sphingobacteriaceae. The only polyamine of strains $4 \mathrm{M} 29^{\mathrm{T}}$ and $4 \mathrm{M}^{\mathrm{T}} 0^{\mathrm{T}}$ was homospermidine. Homospermidine is the major polyamine in members of the family Sphingobacteriaceae. The major polar lipid of strains $4 \mathrm{M} 29^{\mathrm{T}}$ and $4 \mathrm{M} 40^{\mathrm{T}}$ and Parapedobacter koreensis Jip $14^{\mathrm{T}}$ was phosphatidylethanolamine, and several unknown polar lipids were also detected; these three strains also contained sphingolipid, the characteristic polar lipid of members of the family Sphingobacteriaceae (see Supplementary Fig. S1 in IJSEM Online). The DNA $\mathrm{G}+\mathrm{C}$ contents of strains $4 \mathrm{M} 29^{\mathrm{T}}$ and $4 \mathrm{M} 40^{\mathrm{T}}$ were 47.6 and $48.6 \mathrm{~mol} \%$, respectively.

Phenotypic characteristics including Gram staining, catalase and oxidase activities and hydrolysis of CM-cellulose, casein, chitin, DNA, tyrosine, Tween 80 and starch were assessed according to the methods of Smibert \& Krieg (1994). Cell morphology and motility and the presence of flagella were observed by phase-contrast and transmission electron microscopy. For the latter, cells were negatively

Table 1. Cellular fatty acid profiles (\%) of strains $4 \mathrm{M} 29^{\top}$ and $4 \mathrm{M} 40^{\top}$ and the type strains of recognized Parapedobacter species

Strains: $1,4 \mathrm{M} 29^{\mathrm{T}} ; 2,4 \mathrm{M} 40^{\mathrm{T}} ; 3$, P. koreensis $\mathrm{Jip} 14^{\mathrm{T}}$ (data from Kim et al., 2007); 4, P. soli DCY14 ${ }^{\mathrm{T}}$ (Kim et al., 2008). All strains were grown on TSA at $30{ }^{\circ} \mathrm{C}$ for 2 days. Fatty acids amounting to $<1 \%$ in all strains are not shown. tr, Trace $(<1 \%) ;-$, not detected.

\begin{tabular}{|lcccc|}
\hline Fatty acid & $\mathbf{1}$ & $\mathbf{2}$ & $\mathbf{3}$ & $\mathbf{4}$ \\
\hline anteiso- $\mathrm{C}_{13: 0}$ & - & - & - & 11.4 \\
$\mathrm{C}_{14: 0}$ & $\operatorname{tr}$ & $\operatorname{tr}$ & 1.1 & - \\
$\mathrm{C}_{15: 0} 3-\mathrm{OH}$ & - & - & 1.7 & - \\
iso-C $_{15: 0}$ & 48.5 & 42.9 & 33.6 & 29.3 \\
iso-C $_{15: 0} 3-\mathrm{OH}$ & 2.4 & 3.1 & 2.3 & 3.7 \\
$\mathrm{C}_{15: 1} \omega 6 c$ & - & - & 1.1 & - \\
$\mathrm{C}_{16: 0}$ & 1.6 & $\operatorname{tr}$ & 6.0 & 2.7 \\
$\mathrm{C}_{16: 0} 2-\mathrm{OH}$ & $\operatorname{tr}$ & - & 1.1 & - \\
$\mathrm{C}_{16: 0} 3-\mathrm{OH}$ & $\operatorname{tr}$ & $\operatorname{tr}$ & 1.9 & 2.3 \\
$10-\mathrm{Methyl} \mathrm{C} \mathrm{C}_{16: 0}$ & - & - & 7.1 & - \\
anteiso-C & - & - & - & 3.1 \\
iso-C $17: 0$ & 13.3 & 17.6 & 14.4 & 16.3 \\
iso-C $\mathrm{C}_{17: 1} \omega 9 c$ & 7.1 & 11.0 & - & 7.1 \\
$\mathrm{C}_{18: 0}$ & - & - & - & 1.2 \\
ECL 13.566 & 2.5 & 5.4 & $\operatorname{tr}$ & - \\
ECL 16.580 & - & - & - & 1.1 \\
ECL 16.582 & 1.4 & 1.7 & $\operatorname{tr}$ & - \\
Summed feature $3 *$ & 18.1 & 14.2 & 27.8 & 19.4 \\
Summed feature $8^{*}$ & - & - & - & 1.2 \\
& & & & \\
\hline
\end{tabular}

*Summed features are groups of two or three fatty acids that could not be separated by GLC with the Microbial Identification System (MIDI). Summed feature 3 comprised iso- $\mathrm{C}_{15: 0} 2-\mathrm{OH}$ and/or $\mathrm{C}_{16: 1} \omega 7 c$. Summed feature 8 comprised $\mathrm{C}_{19: 1} \omega 11 c$ and/or unknown ECL 18.756 . stained with $0.5 \%$ uranyl acetate. Growth under anaerobic conditions was tested in a GasPak (BBL) jar at $30{ }^{\circ} \mathrm{C}$ for 15 days on TSA. Flexirubin-type pigments were revealed based on the colour shift that occurred after exposure of the colonies to a $20 \%(\mathrm{w} / \mathrm{v}) \mathrm{KOH}$ solution (Reichenbach, 1992). Growth was assessed at 5, 10, 15, 20, 25, 30, 33, 35, 40, 45 and $50{ }^{\circ} \mathrm{C}$ on R2A agar (Reasoner \& Geldreich, 1985). The $\mathrm{pH}$ range for growth was determined in $\mathrm{R} 2 \mathrm{~A}$ broth that was buffered at $\mathrm{pH} 4.0-10.0$ (at intervals of 1.0 $\mathrm{pH}$ unit) with citrate/phosphate or Tris/ $\mathrm{HCl}$ buffer (Breznak \& Costilow, 1994). NaCl tolerance was tested in R2A broth supplemented with $0,1,2,3,5$ and $7 \%(w / v)$ $\mathrm{NaCl}$. Other biochemical tests were carried out by using the API 20 NE, API ID 32GN and API ZYM test kits according to the manufacturer's instructions (bioMérieux).

Strains $4 \mathrm{M} 29^{\mathrm{T}}$ and $4 \mathrm{M} 40^{\mathrm{T}}$ could be differentiated based on colony colour, hydrolysis of Tween 80 , assimilation of Dribose and L-proline and the presence of cystine arylamidase, $\alpha$-chymotrypsin and $\alpha$-fucosidase activities. Differential characteristics between strains $4 \mathrm{M} 29^{\mathrm{T}}$ and $4 \mathrm{M} 40^{\mathrm{T}}$, Parapedobacter koreensis $\mathrm{Jip} 14^{\mathrm{T}}$ and Parapedobacter soli DCY $14^{\mathrm{T}}$ are provided in Table 2 . On the basis of phenotypic data and phylogenetic inference, strains $4 \mathrm{M} 29^{\mathrm{T}}$ and $4 \mathrm{M} 40^{\mathrm{T}}$ are considered to represent two novel species of the genus Parapedobacter, for which the names Parapedobacter luteus sp. nov. and Parapedobacter compost $i$ sp. nov., respectively, are proposed.

\section{Description of Parapedobacter luteus sp. nov.}

Parapedobacter luteus (lu'te.us. L. masc. adj. luteus golden yellow, reflecting the colour of colonies).

Cells are aerobic, Gram-reaction-negative, non-motile, nonspore-forming rods $(0.5 \mu \mathrm{m}$ in diameter and $1.3-2.5 \mu \mathrm{m}$ long). On R2A agar, colonies are circular with regular margins, convex and yellow. Growth occurs at $15-45{ }^{\circ} \mathrm{C}$, at pH $6.0-8.0$ and in the presence of $0-5 \% \mathrm{NaCl}$. Optimum growth occurs at $30{ }^{\circ} \mathrm{C}$, at $\mathrm{pH} 7.0$ and in the absence of $\mathrm{NaCl}$. Catalase- and oxidase-positive. Flexirubin-type pigments are produced. Nitrate is not reduced. Starch and Tween 80 are hydrolysed, but casein, chitin, CM-cellulose, DNA and tyrosine are not. Positive for aesculin hydrolysis, but negative for indole production, glucose fermentation, arginine dihydrolase and urease activities and gelatin hydrolysis (API 20 $\mathrm{NE}$ ). Assimilates D-glucose, L-arabinose, D-mannose, $\mathrm{N}$ acetylglucosamine, maltose, L-rhamnose, sucrose, glycogen, salicin, melibiose and L-proline, but not D-mannitol, potassium gluconate, capric acid, adipic acid, malic acid, trisodium citrate, phenylacetic acid, D-ribose, inositol, itaconic acid, suberic acid, sodium malonate, sodium acetate, lactic acid, L-alanine, potassium 5-ketogluconate, 3-hydroxybenzoic acid, L-serine, L-fucose, D-sorbitol, propionic acid, valeric acid, L-histidine, potassium 2-ketogluconate, 3-hydroxybutyric acid or 4-hydroxybenzoic acid (API $20 \mathrm{NE}$ and API ID 32GN). Positive for alkaline phosphatase, leucine arylamidase, valine arylamidase, cystine arylamidase, trypsin, $\alpha$-chymotrypsin, acid phosphatase, naphthol-AS-BI- 
Table 2. Differential phenotypic characteristics between strains $4 \mathrm{M} 29^{\top}$ and $4 \mathrm{M} 40^{\top}$ and the type strains of recognized Parapedobacter species

Strains: $1,4 \mathrm{M} 29^{\mathrm{T}} ; 2,4 \mathrm{M} 40^{\mathrm{T}} ; 3$, P. koreensis $\mathrm{Jip} 4^{\mathrm{T}}$ (unless indicated, data from Kim et al., 2007, 2008); 4, P. soli DCY14 ${ }^{\mathrm{T}}$ (Kim et al., 2008).

\begin{tabular}{|c|c|c|c|c|}
\hline Characteristic & 1 & 2 & 3 & 4 \\
\hline Colony colour ${ }^{\star}$ & Y & WH & $\mathrm{LY}^{\dagger}$ & $\mathrm{Y}$ \\
\hline Flexirubin pigments & + & - & $+\dagger$ & $+\dagger$ \\
\hline Growth at $42{ }^{\circ} \mathrm{C}$ & + & + & + & - \\
\hline Hydrolysis of Tween 80 & + & - & $-\dagger$ & $-\dagger$ \\
\hline \multicolumn{5}{|l|}{ Assimilation of: } \\
\hline L-Arabinose & + & + & - & + \\
\hline D-Mannitol & - & - & + & + \\
\hline L-Rhamnose & + & + & - & + \\
\hline D-Ribose & - & + & + & + \\
\hline Inositol & - & - & + & - \\
\hline Glycogen & + & + & - & + \\
\hline L-Serine & - & - & + & - \\
\hline Melibiose & + & + & - & + \\
\hline L-Fucose & - & - & + & - \\
\hline D-Sorbitol & - & - & + & + \\
\hline L-Proline & + & - & - & - \\
\hline \multicolumn{5}{|l|}{ Enzyme activities } \\
\hline Valine arylamidase & + & + & + & - \\
\hline Cystine arylamidase & + & - & + & - \\
\hline Trypsin & + & + & + & - \\
\hline$\alpha$-Chymotrypsin & + & - & + & - \\
\hline$\alpha$-Mannosidase & + & + & - & + \\
\hline$\alpha$-Fucosidase & - & + & - & - \\
\hline DNA G $+C$ content $(\mathrm{mol} \%)$ & 47.6 & 48.6 & 45.6 & 50.1 \\
\hline
\end{tabular}

${ }^{*}$ LY, Light yellow; WH, white; Y, yellow.

$\dagger$ Data from the present study.

phosphohydrolase, $\alpha$-galactosidase, $\beta$-galactosidase, $\alpha$-glucosidase, $\beta$-glucosidase, $N$-acetyl- $\beta$-glucosaminidase and $\alpha$ mannosidase activities, but negative for esterase (C4), esterase lipase (C8), lipase (C14), $\beta$-glucuronidase and $\alpha$-fucosidase activities (API ZYM). The major fatty acids $(>13 \%$ of the total) are iso- $\mathrm{C}_{15: 0}$, iso- $\mathrm{C}_{17: 0} 3-\mathrm{OH}$ and summed feature 3 (comprising iso- $\mathrm{C}_{15: 0} 2-\mathrm{OH}$ and/or $\mathrm{C}_{16: 1} \omega 7 c$ ). The complete fatty acid composition of the type strain is given in Table 1 . The predominant isoprenoid quinone is MK-7. The major polar lipid is phosphatidylethanolamine; sphingolipid, an unknown phospholipid, an unknown aminolipid and several unknown polar lipids are also detected. The only polyamine is homospermidine. The DNA G $+\mathrm{C}$ content of the type strain is $47.6 \mathrm{~mol} \%$.

The type strain, $4 \mathrm{M} 29^{\mathrm{T}}\left(=\mathrm{KACC} 10955^{\mathrm{T}}=\mathrm{JCM} 15977^{\mathrm{T}}\right)$, was isolated from cotton waste compost in Korea.

\section{Description of Parapedobacter composti sp. nov.}

Parapedobacter composti (com.pos' ti. L. gen. n. composti of/ from compost).
Cells are aerobic, Gram-reaction-negative, non-motile, non-spore-forming rods $(0.2-0.5 \mu \mathrm{m}$ in diameter and 1.2-5 $\mu \mathrm{m}$ long). On R2A agar, colonies are circular with regular margins, convex and white. Growth occurs at $15-45{ }^{\circ} \mathrm{C}$, at $\mathrm{pH} 6.0-8.0$ and in the presence of $0-5 \%$ $\mathrm{NaCl}$. Optimum growth occurs at $30{ }^{\circ} \mathrm{C}$, at $\mathrm{pH} 7.0$ and in the absence of $\mathrm{NaCl}$. Catalase- and oxidase-positive. Flexirubin-type pigments are not produced. Nitrate is not reduced. Starch is hydrolysed, but casein, chitin, CMcellulose, DNA, Tween 80 and tyrosine are not. Positive for aesculin hydrolysis, but negative for indole production, glucose fermentation, arginine dihydrolase and urease activities and gelatin hydrolysis (API $20 \mathrm{NE}$ ). Assimilates D-glucose, L-arabinose, D-mannose, $\mathrm{N}$-acetylglucosamine, maltose, L-rhamnose, D-ribose, sucrose, glycogen, salicin and melibiose, but not D-mannitol, potassium gluconate, capric acid, adipic acid, malic acid, trisodium citrate, phenylacetic acid, inositol, itaconic acid, suberic acid, sodium malonate, sodium acetate, lactic acid, L-alanine, potassium 5-ketogluconate, 3-hydroxybenzoic acid, Lserine, L-fucose, D-sorbitol, propionic acid, valeric acid, L-histidine, potassium 2-ketogluconate, 3-hydroxybutyric acid, 4-hydroxybenzoic acid or L-proline (API $20 \mathrm{NE}$ and API ID 32GN). Positive for alkaline phosphatase, leucine arylamidase, valine arylamidase, trypsin, acid phosphatase, naphthol-AS-BI-phosphohydrolase, $\alpha$-galactosidase, $\alpha$ glucosidase, $\beta$-glucosidase, $N$-acetyl- $\beta$-glucosaminidase, $\alpha$ mannosidase and $\alpha$-fucosidase activities, but negative for esterase (C4), esterase lipase (C8), lipase (C14), cystine arylamidase, $\alpha$-chymotrypsin, $\beta$-galactosidase and $\beta$ glucuronidase activities (API ZYM). The major fatty acids $\left(>14 \%\right.$ of the total) are iso- $\mathrm{C}_{15: 0}$, iso- $\mathrm{C}_{17: 0} 3-\mathrm{OH}$ and summed feature 3 (comprising iso- $\mathrm{C}_{15: 0} 2-\mathrm{OH}$ and/ or $\left.\mathrm{C}_{16: 1} \omega 7 \mathrm{c}\right)$. The complete fatty acid composition of the type strain is given in Table 1. The predominant isoprenoid quinone is MK-7. The major polar lipid is phosphatidylethanolamine; sphingolipid, an unknown aminolipid and several unknown polar lipids are also detected. The only polyamine is homospermidine. The DNA $\mathrm{G}+\mathrm{C}$ content of the type strain is $48.6 \mathrm{~mol} \%$.

The type strain, $4 \mathrm{M} 40^{\mathrm{T}}\left(=\mathrm{KACC} 10972^{\mathrm{T}}=\mathrm{JCM} 15978^{\mathrm{T}}\right)$, was isolated from cotton waste compost in Korea.

\section{Acknowledgements}

This work was supported by the National Academy of Agricultural Science (NAAS), Rural Development Administration, Republic of Korea.

\section{References}

Asker, D., Beppu, T. \& Ueda, K. (2008). Nubsella zeaxanthinifaciens gen. nov., sp. nov., a zeaxanthin-producing bacterium of the family Sphingobacteriaceae isolated from freshwater. Int J Syst Evol Microbiol 58, 601-606.

Breznak, J. A. \& Costilow, R. N. (1994). Physicochemical factors in growth. In Methods for General and Molecular Bacteriology, pp. 137- 
154. Edited by P. Gerhardt, R. G. E. Murray, W. A. Wood \& N. R. Krieg. Washington, DC: American Society for Microbiology.

Busse, H.-J. \& Auling, G. (1988). Polyamine pattern as a chemotaxonomic marker within the Proteobacteria. Syst Appl Microbiol 11, 1-8.

Busse, H.-J., Bunka, S., Hensel, A. \& Lubitz, W. (1997). Discrimination of members of the family Pasteurellaceae based on polyamine patterns. Int J Syst Bacteriol 47, 698-708.

Groth, I., Schumann, P., Weiss, N., Martin, K. \& Rainey, F. A. (1996). Agrococcus jenensis gen. nov., sp. nov., a new genus of actinomycetes with diaminobutyric acid in the cell wall. Int J Syst Bacteriol 46, 234239.

Hiraishi, A. (1992). Direct automated sequencing of $16 \mathrm{~S}$ rDNA amplified by polymerase chain reaction from bacterial cultures without DNA purification. Lett Appl Microbiol 15, 210-213.

Kim, M. K., Na, J. R., Cho, D. H., Soung, N. K. \& Yang, D. C. (2007). Parapedobacter koreensis gen. nov., sp. nov. Int J Syst Evol Microbiol 57, 1336-1341.

Kim, M. K., Kim, Y. A., Kim, Y. J., Soung, N. K., Yi, T. H., Kim, S. Y. \& Yang, D. C. (2008). Parapedobacter soli sp. nov., isolated from soil of a ginseng field. Int J Syst Evol Microbiol 58, 337-340.

Kumar, S., Tamura, K. \& Nei, M. (2004). MEGA 3: integrated software for molecular evolutionary genetics analysis and sequence alignment. Brief Bioinform 5, 150-163.

Mesbah, M., Premachandran, U. \& Whitman, W. B. (1989). Precise measurement of the $\mathrm{G}+\mathrm{C}$ content of deoxyribonucleic acid by highperformance liquid chromatography. Int J Syst Bacteriol 39, 159-167.

MIDI (1999). Sherlock Microbial Identification System Operating Manual, version 3.0. Newark, DE: MIDI Inc.

Minnikin, D. E., O'Donnell, A. G., Goodfellow, M., Alderson, G., Athalye, M., Schaal, A. \& Parlett, J. H. (1984). An integrated procedure for the extraction of bacterial isoprenoid quinones and polar lipids. J Microbiol Methods 2, 233-241.

Ntougias, S., Fasseas, C. \& Zervakis, G. I. (2007). Olivibacter sitiensis gen. nov., sp. nov., isolated from alkaline olive-oil mill wastes in the region of Sitia, Crete. Int J Syst Evol Microbiol 57, 398-404.

Pankratov, T. A., Tindall, B. J., Liesack, W. \& Dedysh, S. N. (2007). Mucilaginibacter paludis gen. nov., sp. nov. and Mucilaginibacter gracilis sp. nov., pectin-, xylan- and laminarin-degrading members of the family Sphingobacteriaceae from acidic Sphagnum peat bog. Int $J$ Syst Evol Microbiol 57, 2349-2354.

Reasoner, D. J. \& Geldreich, E. E. (1985). A new medium for the enumeration and subculture of bacteria from potable water. Appl Environ Microbiol 49, 1-7.

Reichenbach, H. (1992). The order Cytophagales. In The Prokaryotes, 2nd edn, vol. 4, pp. 3631-3675. Edited by A. Balows, H. G. Trüper, M. Dworkin, W. Harder \& K. H. Schleifer. New York: Springer.

Sasser, M. (1990). Identification of bacteria by gas chromatography of cellular fatty acids, MIDI Technical Note 101. Newark, DE: MIDI Inc.

Seldin, L. \& Dubnau, D. (1985). Deoxyribonucleic acid homology among Bacillus polymyxa, Bacillus macerans, Bacillus azotofixans, and other nitrogen-fixing Bacillus strains. Int J Syst Bacteriol 35, 151-154.

Smibert, R. M. \& Krieg, N. R. (1994). Phenotypic characterization. In Methods for General and Molecular Bacteriology, pp. 607-654. Edited by P. Gerhardt, R. G. E. Murray, W. A. Wood \& N. R. Krieg. Washington, DC: American Society for Microbiology.

Steyn, P. L., Segers, P., Vancanneyt, M., Sandra, P., Kersters, K. \& Joubert, J. J. (1998). Classification of heparinolytic bacteria into a new genus, Pedobacter, comprising four species: Pedobacter heparinus comb. nov., Pedobacter piscium comb. nov., Pedobacter africanus sp. nov. and Pedobacter saltans sp. nov. Proposal of the family Sphingobacteriaceae fam. nov. Int J Syst Bacteriol 48, 165-177.

Vaz-Moreira, I., Nobre, M. F., Nunes, O. C. \& Manaia, C. M. (2007). Pseudosphingobacterium domesticum gen. nov., sp. nov., isolated from home-made compost. Int J Syst Evol Microbiol 57, 1535-1538.

Weisburg, W. G., Barns, S. M., Pelletier, D. A. \& Lane, D. J. (1991). 16 S ribosomal DNA amplification for phylogenetic study. J Bacteriol 173, 697-703.

Weon, H. Y., Kim, B. Y., Lee, C. M., Hong, S. B., Jeon, Y. A., Koo, B. S. \& Kwon, S. W. (2009). Solitalea koreensis gen. nov., sp. nov. and the reclassification of [Flexibacter] canadensis as Solitalea canadensis comb. nov. Int J Syst Evol Microbiol 59, 1969-1975.

Yabuuchi, E., Kaneko, T., Yano, I., Moss, C. W. \& Miyoshi, N. (1983). Sphingobacterium gen. nov., Sphingobacterium spiritivorum comb. nov., Sphingobacterium multivorum comb. nov., Sphingobacterium mizutae sp. nov., and Flavobacterium indologenes sp. nov.: glucosenonfermenting gram-negative rods in CDC groups IIK-2 and IIb. Int $J$ Syst Bacteriol 33, 580-598. 